\title{
Siła złudzeń - informacje o szwedzkich „zwycięstwach” w Rosji i o bitwie połtawskiej dochodzące do obozu króla Stanisława (sierpień 1708-wrzesień 1709 roku)
}

\begin{abstract}
Abstrakt: Artykuł ukazuje trudności w przekazywaniu informacji w czasie kampanii rosyjskiej Karola XII w latach 1708-1709 oraz pojawiające się z tego powodu fałszywe informacje o rzekomych sukcesach szwedzkich, w które bezkrytycznie wierzono w otoczeniu króla Stanisława Leszczyńskiego.

Słowa kluczowe: transfer i wiarygodność informacji, Karol XII, Stanisław Leszczyński, bitwa pod Połtawą
\end{abstract}

Niejednokrotnie już zwracano uwagę w literaturze historycznej poświęconej dziejom nie tylko dawnej Rzeczypospolitej na zjawisko dezinformacji opinii publicznej, na szerzenie się niesprawdzonych plotek, wreszcie na uporczywe nieprzyjmowanie do wiadomości doniesień niekorzystnych dla odbiorców i łudzenie się, że kolejne nowiny przyniosą zupełnie inny obraz sytuacji ${ }^{1}$. To charakterystyczne zjawisko jest dobrze widoczne na przykładzie docierania na ziemie polskie informacji o marszu wojsk szwedzkich w głąb Rosji w 1708 roku i o bezprzykładnej klęsce armii Karola XII pod Połtawą w lipcu 1709 roku². Wśród konfederatów sandomierskich

\footnotetext{
${ }^{1}$ Zob. m.in. B. PopıoŁek: Między prawda a plotką. Prasa rękopiśmienna epoki saskiej jako źródło do historii mentalności. W: Sic erat in fatis. Studia i szkice historyczne dedykowane Profesorowi Bogdanowi Rokowi. T. 2. Red. E. Kościk, R. Żerelik, P. Badyna, F. Wolański. Toruń 2012, s. 295-309; a także szersze ujęcie tej tematyki: K. MALIszewski: Komunikacja społeczna w kulturze staropolskiej. Toruń 2001, s. 27-49, 146-147; P. Dobrowolski: Świat ze słów. Angielskie miesięczniki XVIII w. Media, informacja i opinia publiczna. Warszawa 2018, s. 27, 37-39, 87-102, 338-339.

${ }^{2}$ K. Maliszewski: Komunikacja społeczna w kulturze staropolskiej..., s. 150 (sprzeczne wiadomości o bitwie pod Połtawą); M. BARzDEvičA: Rozpowszechnianie informacji o działaniach
} 
skupionych wokół hetmana wielkiego koronnego Adama Sieniawskiego wiadomość o zwycięstwie cara Piotra I wywołała natychmiastowy odruch radości i triumfu. Stronnicy sprzymierzonego ze Szwedami króla Stanisława Leszczyńskiego, a także przebywający w jego otoczeniu oficerowie szwedzcy przez długi czas negowali prawdziwość tych doniesień i przyjmowali za dobrą monetę każdą plotkę o rzekomej klęsce Piotra I w bitwie połtawskiej. Podstawę źródłową niniejszego artykułu stanowią przede wszystkim listy królewskiego sekretarza Jozafata Michała Karpia (1679-1739), późniejszego (od 1737) biskupa żmudzkiego, regularnie pisane do kanclerza wielkiego litewskiego Karola Stanisława Radziwiłła, z którym był blisko związany ${ }^{3}$.

Król Stanisław, przebywający od września 1707 roku wraz z Karolem XII w Saksonii, we wrześniu 1708 roku wraz z całą armią szwedzką powrócił do Rzeczypospolitej i towarzyszył szwedzkiemu monarsze w jego wyprawie na Litwę, skąd miał wspólnie ze Szwedami pójść w głąb Rosji, na Moskwę. Ostatecznie Karol XII pozwolił mu jednak powrócić do Polski. Po pokonaniu konfederatów sandomierskich wraz ze wspomagającymi go oddziałami szwedzkimi gen. Ernsta Detlofa Krassowa (Krassau’a) powinien udać się na Ukrainę i rozbić, z pomocą Kozaków i Tatarów, znajdujące się tam jeszcze wojska rosyjskie ${ }^{4}$. Lato i jesień 1708 roku spędził Leszczyński w Prusach Królewskich, po czym powolnym marszem przesuwał się przez Mazowsze, Podlasie i Lubelskie w stronę województwa ruskiego. Klęska wojsk stanisławowskich, dowodzonych przez Józefa Potockiego, w bitwie pod Koniecpolem (21 listopada 1708) sprawiła, że cały ten plan stał się znacznie trudniejszy do zrealizowania, niż to sobie wyobrażał Karol XII. Mimo to dzięki przejściowym sukcesom wojsk litewskich hetmana Jana Kazimierza Sapiehy ${ }^{5}$ udało się królowi Stanisławowi wkroczyć 12 kwietnia 1709 roku do Lwowa. Pojawienie się na Woły-

wojennych w Rydze w czasie wielkiej wojny pótnocnej. W: Wojny pótnocne w XVI-XVII wieku. Red. B. Dybaś, A. Ziemlewska. Toruń 2007, s. 183-187; J. Porazinski: Dezinformacja i propaganda $w$ dobie wielkiej wojny pótnocnej. Jan Stanisław Jabłonowski - moralista i manipulator? W: Między barokiem a oświeceniem. T. 9: Wielkie bitwy. Red. S. Aснгемсzy . Olsztyn 2010, s. 18-24; A. PerŁa Kowsкi: Plotki, sprzeczne informacje i gra pozorów. Działalność Stanisława Krosnowskiego, regimentarza Adama Mikołaja Sieniawskiego, hetmana wielkiego koronnego w latach 1707-1709. W: Historia na źródłach oparta. Studia ofiarowane Profesorowi Tadeuszowi Srogoszowi w 65. rocznice urodzin. Red. A. Stroynowski. Częstochowa 2017, s. 259-278.

3 Archiwum Główne Akt Dawnych w Warszawie (dalej: AGAD), Archiwum Radziwiłłów (AR), dz. V, t. 6460, 6465. Listy te zostały niedawno opublikowane drukiem, zob. Przy boku króla Stanisława Leszczyńskiego (1706-1709). T. 2: W wędrówkach po Polsce między Gdańskiem a Lwowem w latach 1708-1709. Listy królewskiego sekretarza Jozefata Michala Karpia oraz fragmenty z gazet pisanych i diariuszy. Wyd. J. DygdaŁA. Warszawa 2019.

4 J. DygdaŁa: Od Torunia do Wilna podróż króla Stanisława zima 1708 roku. „Zapiski Historyczne” 2017, 82, z. 2, s. 85-99; Z. ANUsik: Karol XII. Wrocław 2006, s. 171-184.

5 T. CIESIElSKI: Kariera wojskowa Jana Kazimierza Sapiehy. W: Wielkie rody dawnej Rzeczypospolitej XVI-XIX wieku. T. 1: Sapiehowie. Red. T. CiesIelski, M. SAw ICKi. Opole 2018, s. 346356. 
niu znacznych sił rosyjskich wspierających oddziały koronne hetmana Adama Sieniawskiego uniemożliwiło dalsze posuwanie się wojsk Leszczyńskiego w kierunku Kijowa. 21 kwietnia król Stanisław opuścił Lwów. Rozpoczął się powolny odwrót i oczekiwanie na przybycie nowych szwedzkich posiłków, które wyruszyły wprawdzie z Pomorza Szwedzkiego, ale potem na długo zatrzymały się w Wielkopolsce, ściągając żywność i paszę oraz nakładając wysokie kontrybucje pieniężne ${ }^{6}$. Stanisław Leszczyński wraz ze szwedzkim korpusem gen. E.D. Krassowa przez Jarosław, Łańcut, Sędziszów Małopolski dotarł w końcu czerwca 1709 roku do Szczucina nad Wisłą, gdzie stał aż do 25 lipca, po czym od 30 lipca przebywał w Opatowcu, już na lewym brzegu rzeki. Stamtąd w drugiej połowie sierpnia przeniósł się do Koprzywnicy, potem obawiając się zbliżających wojsk rosyjskich i saskich, skierował się na zachód, przechodząc we wrześniu 1709 roku przez Sandomierskie i Wielkopolskę do szwedzkiego Szczecina.

Podczas pobytu króla Stanisława w Malborku, latem 1708 roku, dotarła tam wiadomość o zwycięstwie Karola XII nad wojskami rosyjskimi pod Hołowczynem na Białorusi. $Z$ tej okazji biskup chełmiński Teodor Potocki ok. 10 sierpnia 1708 roku odprawił w Malborku, zapewne w kościele zamkowym, mszę dziękczynną. Odśpiewano Te Deum laudamus, oddano salwę z dział, a monarcha wyprawił ucztę ${ }^{7}$. Bitwa pod Hołowczynem odbyła się 15 lipca 1708 roku i zakończyła się rozbiciem głównych sił rosyjskich, które jednak zdołały wycofać się przy stosunkowo niewielkich stratach ${ }^{8}$. W sąsiednim Gdańsku tydzień później wiedziano jednak, że sukces szwedzki nie był tak wielki, jak początkowo sądzono, bowiem żołnierze rosyjscy stawiali zdecydowany opór. Co więcej, podobno to Szwedzi ponieśli znacznie większe straty, gdyż miało ich zginąć aż 8 tys., podczas gdy straty Rosjan szacowano jedynie na tysiąc osób9 ${ }^{9}$ W rzeczywistości Szwedzi stracili jedynie ok. 300 żołnierzy, a tysiąc zostało rannych, natomiast Rosjan zginęło blisko 1700.

Późniejsze informacje docierające na dwór Stanisława Leszczyńskiego mówiły o powolnym posuwaniu się Szwedów na wschód i o stopniowym wycofywaniu się Rosjan, unikających wydania walnej bitwy. Wszystko wskazywało na to, że zdecydowaną przewagę miały wojska szwedzkie, choć odczuwały one trudy tej ofen-

${ }^{6}$ E. CieŚla : Stanisław Leszczyński. Wrocław-Warszawa-Kraków 1994, s. 56-61; J.A. GieRowski: Stanisław Bogusław Leszczyński h. Wieniawa (1677-1766), król Polski, książę Lotaryngii. W: IDEM: Na szlakach Rzeczypospolitej w nowożytnej Europie. Red. A.K. LinK-LenCzowsKi. Kraków 2008, s. 398-399; J. WimmeR: Wojsko polskie w dobie wojny pótnocnej. Warszawa 1956, s. 315-342.

7 AGAD, AR, dz. XXXIV, nr 235, Gazeta pisana, Z Malborka 11 VIII 1708.

${ }^{8}$ Zob. szerzej L.G. Beskrovny. Strategiâ i taktika russkoj armii v Poltavskij period Severnoj vojny. W: Poltava. K 250-letî̂ poltavskovo srażeniâ. Red. L.G. Beskrovny et al. Moskva 1959, s. 30-31; B. Liljegren: Karol XII. Gdańsk 2015, s. 159-160; P. From: Klęska pod Połtawą. Kampania Karola XII w Rosji w latach 1707-1709. Zabrze 2010, s. 147-170.

9 Archiwum Państwowe w Toruniu (dalej: APT), Kat. II, dz. XIV, t. 78, k. 57, Gazeta pisana, Z Gdańska 18 VIII 1708. 
sywy. W dniu 14 września 1708 roku przyjechał do Malborka jakiś ksiądz z listami z obozu szwedzkiego od płk. Stanisława Poniatowskiego, który pełnił funkcję rezydenta polskiego monarchy przy Karolu XII. Treści owych listów nie ujawniono, ale Stanisław Leszczyński po zapoznaniu się z nimi „znaczne po sobie pokazywał ukontentowanie". Tenże ksiądz mówił, iż Karol XII z całym wojskiem skierował się spod Mohylewa na południe, obchodząc pozycje rosyjskie. Dodawał jednak, że „W wojsku szwedzkim wielka victualium [żywności] drożyzna”. W otoczeniu króla Stanisława panowało przekonanie, że Szwedzi chcą przejść przez Ukrainę i dopiero stamtąd ruszyć na Moskwę ${ }^{10}$. Według francuskiego dyplomaty Jeana Victora de Besenval, który przebywał wówczas w Gdańsku i bezpośrednio kontaktował się z królem, Leszczyński „nie wierzył w złe prognozy” dotyczące moskiewskiej wyprawy Karola XII ${ }^{11}$.

Także kolejne doniesienia napływające z Inflant nie przynosiły jednoznacznych informacji. Najpierw Rosjanie mieli odnieść sukces pod Narwą, ale trzy tygodnie później szwedzki gen. Georg Lybecker miał położyć trupem 4,5 tys. żołnierzy rosyjskich $^{12}$. W rzeczywistości G. Lybecker, który dowodził wówczas armią szwedzką w Finlandii, bezskutecznie próbował zdobyć Petersburg, nowo założone przez Piotra I miasto, na terenach niedawno zdobytych na Szwedach ${ }^{13}$.

Mimo to wśród oficerów szwedzkich i polskich dostojników przebywających przy królu Stanisławie nastroje były bardzo dobre. Wszyscy byli pewni ostatecznego sukcesu Karola XII. Dlatego też 22 listopada 1708 roku śmiechem zareagowano na słowa przybyłego marszałka nadwornego koronnego Stanisława Tarły, który mówił:

że się zjechał z pewnym towarzyszem w drodze, który tę mu czynił relację, jakoby miał biec kurier od cara [Piotra I] do JP w[ojewo]dy bełskiego [Adama Sieniawskiego], pytając się go, co ma czynić car z królem szwedzkim [Karolem XII], czy go żywcem wziąć, czy też zabić. Srodze Król JM [Stanisław] i wszyscy śmieli się z tej bajki ${ }^{14}$.

Podobnie zareagowano na rosyjską pisemną relację o zwycięskiej bitwie z wojskami szwedzkimi gen. Adama Ludviga Lewenhaupta, która dotarła 26 listopada 1708 roku do Stanisława Leszczyńskiego. „Czytał onę Król JM et ex figmentis [i z kłamstw] w onej insertis [włożonych] bardzo się śmiał”15.

\footnotetext{
${ }^{10}$ AGAD, AR, dz. V, t. 6465/III, s. 200-201, J.M. Karp do K.S. Radziwiłła, Malbork 15 IX 1708.

${ }^{11}$ J.A. Gierowski: Stanisław Leszczyński w latach 1707-1709 w opiniach dyplomatów francuskich. „Acta Universitatis Wratislaviensis, Historia” 1981, 36, s. 161.

12 AGAD, AR, dz. V, t. 6465/III, s. 243, 291, J.M. Karp do K.S. Radziwiłła, Malbork 25 IX i 12 X 1708.

${ }^{13}$ P. Krokosz: Rosyjskie sity zbrojne za panowania Piotra I. Kraków 2010, s. 334-335.

${ }^{14}$ AGAD, AR, dz. V, t. 6465/III, s. 326-327, J.M. Karp do K.S. Radziwiłła, Koski 28 XI 1708.

${ }^{15}$ Ibidem, t. 6465/IV, s. 43, J.M. Karp do K.S. Radziwiłła, Koski 28 XI 1708.
} 
O prawdziwym przebiegu wydarzeń dowiedziano się w obozie króla Stanisława następnego dnia. 27 listopada, po obiedzie, przyjechał niejaki ksiądz Piotrowski, wysłany przez gen. A.L. Lewenhaupta z Czerei, miasteczka w powiecie orszańskim. Przywiózł on informację o bitwie stoczonej przez tegoż generała z Rosjanami, która według niego przebiegała niekorzystnie dla Szwedów. Jej ostatecznego wyniku jeszcze nie znał, gdyż został odesłany z pola walki w trakcie bitwy. Porażkę szwedzkiego generała tłumaczył niezastosowaniem się do rozkazów Karola XII. Zamiast możliwie jak najszybciej maszerować w stronę głównych sił szwedzkich stał on dziesięć dni w Czerei, ściągając kontrybucje, co dało Rosjanom czas na koncentrację swych wojsk ${ }^{16}$.

Relacja księdza Piotrowicza dotyczyła bitwy pod Leśną, stoczonej w dniach 9-10 października 1708 roku, w wyniku której gen. A.L. Lewenhaupt utracił większość swej armii idącej z Inflant do Karola XII (w tym wszystkie tabory z zaopatrzeniem dla głównych sił szwedzkich oraz artylerię) i tylko z niewielką częścią żołnierzy udało mu się dotrzeć do szwedzkiego monarchy ${ }^{17}$.

Przy okazji ksiądz Piotrowicz doniósł o wydarzeniach na południu Ukrainy. Miał tam zostać wysłany feldmarszałek Aleksy Daniłowicz Mieńszykow z kilkunastotysięcznym korpusem w celu utrzymania w posłuszeństwie tamtejszych Kozaków. Doszły bowiem do cara Piotra I pogłoski, iż kozacki hetman lewobrzeżnej Ukrainy, Iwan Mazepa, obawiając się Szwedów, którzy skierowali się na południe, gotów jest porozumieć się z nimi i dostarczać im żywność oraz paszę ${ }^{18}$.

W świetle listów Jozafata Michała Karpia byłaby to pierwsza informacja, która dotarła do króla Stanisława, potwierdzająca wcześniejsze przypuszczenia o spodziewanym przejściu Iwana Mazepy i jego Kozaków na stronę szwedzką. I. Mazepa od dawna zachęcany był przez Stanisława Leszczyńskiego, a także przez Wiśniowieckich do tego kroku i składał poufne zapewnienia o wypowiedzeniu posłuszeństwa carowi Piotrowi I. W końcu rzeczywiście zdecydował się przejść na stronę szwedzką, był przy tym pewny, że Kozacy pozyskani obietnicami swobód i niezależności pójdą za nim. Nadzieja na pomoc ze strony Kozaków i na dostawy prowiantu była też jedną z przyczyn zmiany planów Karola XII. Początkowo zamierzał on iść na wschód, bezpośrednio na Moskwę. Tereny, przez które maszerowały wojska szwedzkie, Rosjanie jednak celowo niszczyli, tak że nie było na nich możliwości kwaterunków ani wybierania żywności. Dlatego też Szwedzi skierowali się na Siewierszczyznę, a następnie na południową Ukrainę ${ }^{19}$.

\footnotetext{
${ }_{16}$ AGAD, AR, dz. V, t. 6465/IV, s. 45, J.M. Karp do K.S. Radziwiłła, Koski 28 XI 1708.

17 L.G. Beskrovnyj: Strategiâ i taktika russkoj armii v Poltavskij..., s. 36-39; P. From: Klęska pod Połtawa..., s. 91-124; P. Krokosz: Rosyjskie siły zbrojne za panowania Piotra I..., s. 339341.

${ }_{18}$ AGAD, AR, dz. V, t. 6465/IV, s. 45-46, J.M. Karp do K.S. Radziwiłła, Koski 28 XI 1708.

19 B. Liljegren: Karol XII..., s. 163-164; P. Krokosz: Rosyjskie sity zbrojne za panowania Piotra I..., s. 339, 342-344.
} 
Tydzień później wyraźnie poprawiły się nastroje w obozie króla Stanisława. Dnia 4 grudnia 1708 roku zjawiła się tam wojewodzina kijowska Wiktoria Potocka. Podczas wieczornej gry w karty podała Stanisławowi Leszczyńskiemu gazetę pisaną, otrzymaną od kanclerza litewskiego Karola Stanisława Radziwiłła. Była w niej mowa o przejściu kozackiego hetmana Ukrainy Lewobrzeżnej I. Mazepy wraz z Zaporożcami na stronę Karola XII. Potwierdzało to wcześniejsze przypuszczenia. Jednocześnie jeden ze szwedzkich oficerów - na podstawie gazety pisanej z Mitawy - poinformował zebranych, że gen. A.L. Lewenhaupt stoczył zwycięską bitwę z Rosjanami, w wyniku której zginęło wprawdzie 4 tys. Szwedów, ale też aż 18 tys. żołnierzy rosyjskich, a inny dowódca szwedzki - gen. Karl Gustav Rehnskiöld zaatakował dywizję rosyjskiego feldmarszałka Borysa Piotrowicza Szeremietiewa, który stracił 4 tys. ludzi. Z informacji tych (ewidentnie zresztą nieprawdziwych, jeżeli chodzi o militarne sukcesy szwedzkie) bardzo był zadowolony król Stanisław $i$ jego najbliższe otoczenie ${ }^{20}$.

Kolejne nowiny docierające do obozu króla Stanisława wydawały się jeszcze pomyślniejsze. W połowie grudnia 1708 roku, podczas dłuższego postoju w Wiśniewie, „przyszły dwie poczty razem ze Gdańska, które laetum attulerunt nuntium [wesołą przyniosły wiadomość] o zniesieniu Moskwy w Ukrainie”. Według relacji przysłanej do Gdańska z rosyjskiej twierdzy i miasta Staroduba „wojsko moskiewskie totaliter [całkowicie] jest zniesione, liczy się zginionej Moskwy na $60 \mathrm{~m}$. [tysięcy]". Niejako potwierdził tę wiadomość list od podstolego litewskiego Michała Potockiego. Charakterystyczne jest jednak, że jak zauważył J.M. Karp, wszyscy bardzo niecierpliwie „czekają tu tego konfirmacji” ${ }^{21}$. W końcu grudnia 1708 roku wciąż nie było nowych informacji o sytuacji militarnej na Ukrainie, dotarła tylko wiadomość (zresztą fałszywa), że „Mazepa darował królowi szwedzkiemu ośm tysięcy wołów, dwanaście tysięcy owiec i czternaście tysięcy koni”22.

W połowie stycznia 1709 roku do króla Stanisława dotarł list wysłany z Zamościa przez starostę wiskiego Michała Puzynę. Pisał w nim starosta, iż powszechnie jest już wiadome, że podczas kampanii na Ukrainie zginęło 20 tys. żołnierzy rosyjskich, podczas gdy Karol XII stracił jedynie dwa regimenty. Ponadto Kozacy przystępują do hetmana Iwana Mazepy i niedawno przyszło ich 12 tys. Do tego z Mohylewa powrócił niejaki Juszyński, przywożąc wiadomości o nowych zwycięstwach szwedzkich. Według niego „sama Moskwa [Rosjanie] głosi, cum his particularitatibus [z tymi szczegółami], że $40 \mathrm{~m}$. [tysięcy] Moskwy zginęło, Mężyk [feldmarszałek A.D. Mieńszykow] zabity, car [Piotr I] postrzelony i że po tej batalii prosto król szwedzki [Karol XII] poszedł do stolicy [to jest do Moskwy]”23. Te pomyślne in-

\footnotetext{
20 AGAD, AR, dz. V, t. 6465/IV, s. 69-70, J.M. Karp do K.S. Radziwiłła, Krześlin 6 XII 1708.

${ }^{21}$ Ibidem, s. 79-80, J.M. Karp do K.S. Radziwiłła, Wiśniew 15 XII 1708.

${ }^{22}$ Ibidem, s. 101-102, J.M. Karp do K.S. Radziwiłła, Wiśniew 26 XII 1708.

${ }^{23}$ Ibidem, s. 131-132, J.M. Karp do K.S. Radziwiłła, Tulniki 18 I 1709.
} 
formacje zostały potwierdzone trzy dni później przez Manieckiego (być może Ludwika, chorążego czernihowskiego). Przyjechał on do króla Stanisława wraz z Kozakiem, który pięć tygodni wcześniej wyjechał z Ukrainy. Ten Kozak mówil, że 17 grudnia 1708 roku pod Hadziaczem doszło do bitwy, w której 10 tys. Szwedów całkowicie zniosło 20-tysięczny korpus feldmarszałka A.D. Mieńszykowa. Natomiast 7-tysięczna dywizja feldmarszałka Borysa P. Szeremietiewa idąca na pomoc A.D. Mieńszykowowi została rozbita przez szwedzkiego gen. K.G. Rehnskiölda tak, że rosyjski feldmarszałek „ledwo w 50 koni umknął”. Szwedzi ponieśli podobno tylko niewielkie straty, zginęło natomiast aż 4 tys. Kozaków walczących z Rosjanami. Niepowodzeniem skończyła się natomiast próba obrony Baturynu, w którym zamknęło się 6 tys. Kozaków. Rosjanie zdobyli to miasto i w pień wycięli obrońców. Szwedzi podobno szli z odsieczą, lecz przybyli zbyt późno ${ }^{24}$.

Pod Hadziaczem, zajętym już przez Szwedów i Kozaków I. Mazepy, nie doszło jednak wówczas do żadnej bitwy, Rosjanie podchodząc pod miasto, spalili magazyny z żywnością i zdążyli wycofać się przed nadejściem Karola XII ${ }^{25}$. Tymczasem informacje o rzekomej bitwie pod Hadziaczem długo jeszcze krążyły po Ukrainie i docierały do króla Stanisława. Dnia 1 lutego 1709 roku nadszedł list od podkomorzego krzemienieckiego Stanisława Ledóchowskiego potwierdzający, na podstawie relacji ludzi przybyłych z głębi Ukrainy, wcześniejsze doniesienia i dodający nowe wiadomości, jakoby feldmarszałek B.P. Szeremietiew poddał się Szwedom ${ }^{26}$.

Tymczasem 30 stycznia 1709 roku w dostarczonej do obozu królewskiego poczcie z Gdańska i kilku innych miejscowości znalazły się informacje o zwycięskiej bitwie stoczonej przez Karola XII pod Konotopem (a nie Hadziaczem) 17 grudnia 1708 roku, w której Rosjanie ponieśli ogromne straty. Szwedzi po tym sukcesie mieli szybkim marszem pójść w kierunku Moskwy. Ponadto carewicz Aleksy Piotrowicz według jednych doniesień z kilkunastoma tysiącami żołnierzy poddał się szwedzkiemu monarsze, a według drugich podniósł w samej Moskwie bunt przeciwko ojcu. Ostrożny w doniesieniach J.M. Karp dodał jednak: „o czym zupełniejszej z Ukrainy z obozu szwedzkiego czekamy konfirmacji”27.

W rzeczywistości wszystkie te informacje były nieprawdziwe, gdyż pod Konotopem, podobnie jak i pod Hadziaczem, nie doszło w połowie grudnia 1708 roku do bitwy Szwedów z Rosjanami, a carewicz Aleksy Piotrowicz ani nie poddał się Karolowi XII, ani nie stanął na czele rzekomego buntu przeciwko Piotrowi $\mathrm{I}^{28}$.

${ }^{24}$ Ibidem, s. 140-142, J.M. Karp do K.S. Radziwiłła, Tulniki 21 I 1709. Faktycznie Mazepa przyprowadził z sobą do obozu Karola XII jedynie 4 tys. Kozaków, zob. szerzej P. Krokosz: Rosyjskie sity zbrojne za panowania Piotra I..., s. 342; P. From: Klęska pod Poltawą..., s. 244-247.

${ }_{25}$ P. KRokosz: Rosyjskie sity zbrojne za panowania Piotra I..., s. 344.

${ }^{26}$ AGAD, AR, dz. V, t. 6465/IV, s. 168-169, J.M. Karp do K.S. Radziwiłła, Świerszczów 3 II 1709.

27 Ibidem, s. 163-164, J.M. Karp do K.S. Radziwiłła, Świerszczów 1 II 1709.

${ }^{28}$ Zob. W.A. Serczy K: Piotr I Wielki. Wrocław 1990, s. 138, 155-156. 
Dokładniejsze i bardziej wiarygodne informacje o sytuacji na Ukrainie dotarły do polskiego monarchy dopiero 1 marca 1709 roku. Wojewoda kijowski Józef Potocki przesłał jeńca, kpt. Psarskiego, który bezpośrednio od Piotra I jechał z listami do hetmana A. Sieniawskiego. Tenże Psarski „egzaminowany” przez samego króla Stanisława mówił, że był dwa tygodnie temu w obozie rosyjskim. Oba wojska stoją o trzy mile naprzeciwko siebie. Żadnej bitwy nie było, jedynie podjazdy z obu stron nawzajem się atakowały, przy czym sukcesy odnosili Szwedzi. Według Psarskiego Rosjanie bardzo boją się Szwedów i gotowi byliby zgodzić się na zawarcie pokoju, pod warunkiem zostawienia im Petersburga. Szwedzi są natomiast pewni siebie. Z tych zeznań wynikało, iż większość Kozaków opuściła hetmana I. Mazepę. Podobno Karol XII zupełnie się tym nie przejął i pocieszał I. Mazepę, miał jednak pretensje do swego gen. A.L. Lewenhaupta o przegraną bitwę pod Leśną. Z relacji Psarskiego wynikało, że Piotr I skierował do Polski na Wołyń 8 regimentów, by wzmocnić oddziały wojsk koronnych hetmana A. Sieniawskiego ${ }^{29}$.

Miesiąc później dotarła do króla Stanisława relacja jakiegoś „człowieka, który niedawno aż za Kijowem był”. Potwierdzała ona wcześniejsze doniesienia, „że batalii generalnej żadnej nie było dotąd". Karol XII miał wprawdzie zdobyć kilka niewielkich miasteczek, których załogi nie przekraczały tysiąca żołnierzy, ale według tej relacji czynił to po to, by sprowokować Piotra I do przyjścia tym garnizonom z odsieczą i do doprowadzenia do walnej, rozstrzygającej bitwy. To jednak Szwedom się nie udało. Kozacy zadnieprzańscy mieli ostatecznie przyłączyć się do wojsk szwedzkich. Relacja w tym miejscu jest nieco dwuznaczna, bo informuje, że podobno Karol XII miał skierować się w stronę Kijowa po to, by otworzyć drogę do Polski i zjednoczyć wszystkich Kozaków pod władzą hetmana I. Mazepy. Otwarcie jest w niej mowa, że ,już koło Kijowa wielkie wszczęły się między Kozakami tumulty, jednych za carem, a drugich za Mazepą ciągnących". Podsumowanie tych doniesień było niezwykle pozytywne, bowiem "Szwedzi i na zdrowiu i na wszystkim bardzo się dobrze mają na Ukrainie" ${ }^{\prime 3}$.

Te pomyślne informacje potwierdziły się niejako 6 maja 1709 roku. Z Ukrainy doniesiono, „że król szwedzki [Karol XII] świeżo zbił pięć tysięcy Kałmuków i trzy tysiące Moskwy". Następnego dnia dotarły do króla Stanisława, wciąż przebywającego pod Jarosławiem, znacznie dokładniejsze i bardziej wiarygodne wiadomości. Przybył tam wówczas specjalny wysłannik Karola XII, towarzysz z polskiej chorągwi wołoskiej, będącej na żołdzie szwedzkim. By ominąć wojska rosyjskie i oddziały hetmana A. Sieniawskiego, jechał przez terytorium tureckie i Wołoszczyznę. „Przywiózł listów haniebną moc, co się zaś w nich zawiera nikt jeszcze nie wie, bo zaraz z niemi pobiegł Król JM [Stanisław] do gen. [Ernsta Detlofa] Krassowa [dowódcy korpusu szwedzkiego], plenus gaudii [pełen radości] z odebranej wiadomości”.

29 AGAD, AR, dz. V, t. 6465/V, s. 1-3, J.M. Karp do K.S. Radziwiłła, Krasne 2 III 1709.

30 Ibidem, s. 96-97, J.M. Karp do K.S. Radziwiłła, Wysocko 7 IV 1709. 
W liście polskiego poczmistrza towarzyszącego Karolowi XII, pisanym pod Połtawą 13 kwietnia 1709 roku, J.M. Karp przeczytał m.in.:

Nam tu P[an] Bóg dziwnie assistit [asystuje], bo sami poddani carscy przychodzą do nas i biją Moskwę, a my ledwo co czyniemy, już ze 40 m. [tysięcy] Moskwy zginęło, a pięć tysięcy niewolnika mamy, z któremi nie wiemy co czynić. Poseł tatarski jest u króla szwedzkiego [Karola XII], który z tym jest przysłany, że $50 \mathrm{~m}$. [tysięcy] Tatarów na usługę króla naszego wkrótce ma przyjść i ten poseł nie odjedzie wprzód z obozu szwedzkiego, aż się to ziści.

W kilka chwil później J.M. Karp dowiedział się, że Stanisław Leszczyński otrzymał trzy listy od Karola XII. W pierwszym, datowanym jeszcze na listopad 1708 roku, król szwedzki informował, iż wszedł w granice państwa rosyjskiego. W drugim, z 13 kwietnia 1709 roku, napisał:

Nie wątpię, że różne wieści o mnie i o wojsku moim rozniesione są po Polszcze, lecz ja donoszę, że mi się dobrze, z łaski Bożej, powodziło i powodzi, przy wszelkiej sufficiencii [zaopatrzeniu w żywność]. We wszystkich ile było rankontrach [spotkaniach] żołnierz szwedzki płoszył i bił Moskwę. Trzeba, żebyś W[asza] K[rólewska] M[ość] [Stanisław] pośpieszył tu ad recipienda avulsa et ad exequenda proiecta [dla odzyskania utraconych ziem i dla realizacji planów] prze[ciw]ko nieprzyjacielowi.

Trzeci list napisany był 30 kwietnia 1709 roku, jego treści sekretarz królewski jednak nie znał' ${ }^{31}$.

Przy tej okazji król Stanisław otrzymał także dwa listy, z 27 marca i 13 kwietnia 1709 roku, od płk. Stanisława Poniatowskiego przebywającego przy boku Karola XII. Pisał w nich:

Moskwy na 40 m. [tysięcy] zginęło od wejścia króla szwedzkiego do Ukrainy oprócz pospólstwa dobytego i wyciętego w różnych miastach. Wojska szwedzkiego nad dwa tysiące nie ubyło, ex principalioribus [z dowódców] ci zginęli: pułkownicy Szperling [Jakob Sperling?] i Gildensztern [Nils

${ }^{31}$ Ibidem, s. 151-152, J.M. Karp do K.S. Radziwiłła, Wysocko 7 IV 1709. K. TARnowsKi (Adam Śmigielski, chorąży nadworny koronny, starosta gnieźnieński. „Biblioteka Warszawska” 1850, t. 1, s. 257) myli się więc, twierdząc, że rozkazy Karola XII nie doszły do Lwowa, gdyż „komunikacja była zupełnie przeciętą, przez 8 tygodni nie miano żadnej wiadomości z obozu szwedzkiego”. Faktycznie polecenia Karola XII domagającego się, by korpus gen. Ernsta Detlofa Krassowa i wojska polsko-litewskie króla Stanisława pośpieszyły na Ukrainę, doszły do adresatów, ale nastąpiło to już w momencie ich odwrotu ze Lwowa na zachód. 
Gyllenstierna?], także obersztlejtnant [ppłk] Wrangiel [Henrik Wilhelm Wrangel?], którego król JM [Karol XII] bardzo żałował. Koszowi Kozacy, alias Zaporożcy $\mathrm{z}$ hetmanem swoim [Iwanem Mazepą] przyszli do króla szwedzkiego, przed którym schylali chorągwie, carską i n[ie]b[oszczy]ka Jana króla [Jana III Sobieskiego]. Przed przyjściem zaś swoim wycięli 4 regimenty Moskwy. Tatarscy deputaci są actu [teraz] przy królu szwedzkim, oczekiwając na kilkadziesiąt tysięcy Ordy, która zapewnie ma się złączyć ze Szwedami ${ }^{32}$.

Tydzień później J.M. Karp potwierdził niejako te pomyślne wiadomości, pisząc: „Na Ukrainie Szwedzi mięsa dosyć mają, o chleb i piwo przytrudniej”, a król szwedzki ma swoją kwaterę o 3 mile od Połtawy ${ }^{33}$.

Karol XII rzeczywiście znalazł się pod Połtawą już w pierwszej połowie kwietnia 1709 roku, a w początkach maja rozpoczął regularne oblężenie tego miasta. Jednocześnie Rosjanie zaczęli koncentrować swe siły w pobliżu Połtawy, by udzielić obrońcom pomocy i w sprzyjającej sytuacji uderzyć na Szwedów. Obóz swój, który później przenieśli bliżej miasta, otoczyli szańcami ziemnymi. Kilkakrotne próby Karola XII wzięcia Połtawy szturmem skończyły się niepowodzeniem. Dalsze prace oblężnicze toczyły się wolno, a wojska szwedzkie musiały cały czas być w gotowości, gdyż oddziały rosyjskie wciąż podejmowały próby ataku na wysunięte placówki przeciwnika $^{34}$.

Tymczasem 17 czerwca 1709 roku zjawił się w obozie króla Stanisława, który cofnął się aż pod Sędziszów koło Rzeszowa, jakiś ksiądz z Ukrainy, dostarczając nową porcję informacji. Najważniejsza była wiadomość, że Tatarzy stoją tuż nad granicą i gotowi są wesprzeć Szwedów. Podobno Piotr I miał interweniować w tej sprawie u władz tureckich, które jednak odpowiedziały, „że Porta nie łamie z Moskwą paktów, ale Tatarowie zawsze przy tym wojują, kto im lepiej zapłaci, jeżeli car dobrze ich ujmie, będą i przy carze". Ponadto wybrany na miejsce I. Mazepy nowy hetman kozacki Iwan Skoropadski miał „Z całym wojskiem zadnieprskim” przejść na stronę szwedzką, a do tego miał całkowicie rozbić kilka pułków rosyjskich wysłanych przeciw niemu z Kijowa, tak że ani jeden świadek klęski nie pozostał przy życiu. W odwecie car miał zdobyć Mohylew, spalić miasto i wyciąć jego mieszkań-

32 AGAD, AR, dz. V, t. 6465/V, s. 141-142, J.M. Karp do K.S. Radziwiłła, Wysocko 7 V 1709. Pogłoski o spodziewanym przybyciu kilkudziesięciu tysięcy Tatarów z pomocą Karolowi XII świadomie były rozpowszechniane przez szwedzką kancelarię polową. W istocie sułtan Ahmed III już w końcu maja 1709 roku zakazał chanowi Dewlet Girejowi udzielania jakiejkolwiek pomocy armii szwedzkiej na Ukrainie, zob. P. From: Klęska pod Połtawą..., s. 297-298.

${ }_{33}$ AGAD, AR, dz. V, t. 6465/V, s. 161-162, J.M. Karp do K.S. Radziwiłła, Wysocko 15 V 1709. W rzeczywistości Szwedzi coraz bardziej odczuwali brak żywności, amunicji i prochu.

${ }^{34}$ W.A. Serczy K: Poltawa 1709. Warszawa 1982, s. 116-122; P. KROKOsz: Rosyjskie sity zbrojne za panowania Piotra I..., s. 345-346. 
ców. Z kolei Karol XII pozostawiwszy większość swej armii pod Połtawą, z kilkoma regimentami i wszystkimi Kozakami przeszedł na prawy brzeg Dniepru w celu odebrania Rosjanom Kijowa, „który gdy będzie odebrany, w całej Ukrainie nie będzie miała Moskwa do czego przytulić się"35. J.M. Karp nie zdawał sobie sprawy, że informacje te były całkowicie nieprawdziwe.

Cztery dni później, rankiem 22 czerwca 1709 roku, przyjechał do obozu króla Stanisława chorąży jazdy wołoskiej przysłany przez Karola XII. Złożył szczegółową relację o sytuacji wojsk szwedzkich na Ukrainie pod Połtawą. Mówił, „że król szwedzki stoi między wodami [rzeki Worskli], na których kilka mostów ma Moskwa, lecz przechodzić przez one nie śmie”. Wojska rosyjskie są według niego podzielone na cztery ugrupowania. Z jednej strony stoi feldmarszałek Aleksy Daniłowicz Mieńszykow z 30 tys. żołnierzy, z drugiej — feldmarszałek Borys Piotrowicz Szeremietiew mający pod swą komendą też 30 tys., z trzeciej, od Krymu — gen. Karl Ewald Rőnne z 12 tys., z czwartej strony — gen. książę Grigorij Siemionowicz Wołkoński z 10 tys. ludzi, z piątej - niejaki Łuckin (?) z 6 tys. i z szóstej - gen. Beim (zapewne Rodion Bauer, ewentualnie Jakub Bruce) z 5 tys., który to Beim ma poufne kontakty ze Szwedami i często informuje ich o zamierzeniach Rosjan. Łączna liczba żołnierzy rosyjskich zgromadzonych na południu Ukrainy wynosiłaby więc przeszło 90 tys., podczas gdy liczebność wojsk szwedzkich tenże chorąży szacował na 30 tys., w tym 3,5 tys. chorych. Dodał przy tym, iż podczas niezwykle surowej zimy zmarło z powodu mrozów 8 tys. żołnierzy rosyjskich, a także wielu szwedzkich. $\mathrm{Z}$ relacji tej wynikało, że tymczasem Szwedzi nie mogą liczyć na pomoc Tatarów, gdyż wszystkie drogi z Krymu na Ukrainę są zatarasowane i dopiero po zdobyciu Połtawy Karol XII mógłby je uczynić przejezdnymi. Podobno szwedzki monarcha ceni bardzo Kozaków, którzy niezwykle celnie strzelają ze swych samopałów, a hetman I. Mazepa ma być u niego w takiej samej „powadze, w jakiej był nieboszczyk JMP podskarbi WXL", czyli Benedykt Sapieha ${ }^{36}$.

Trudno powiedzieć, czy to na podstawie relacji tegoż chorążego, czy też innych doniesień pojawiły się przed 26 czerwca 1709 roku w otoczeniu króla Stanisława pogłoski, jakoby pod Połtawą doszło do bitwy zakończonej wielkim zwycięstwem Karola XII, podczas której miał zginąć feldmarszałek B.P. Szeremietiew, a książę

${ }^{35}$ AGAD, AR, dz. V, t. 6465/V, s. 200-202, J.M. Karp do K.S. Radziwiłła, Szopnica pod Sędziszowem 18 VI 1709.

${ }^{36}$ AGAD, AR, dz. V, t. 6465/II, s. 105-107, J.M. Karp do K.S. Radziwiłła, Szczucin 24 VI 1709. W rzeczywistości załoga Połtawy liczyła przeszło 4 tys. żołnierzy, a armia Piotra I ok. 45 tys. (według innych źródeł nawet 55 tys.). Liczebność wojsk Karola XII na południowej Ukrainie szacowano na 28 tys. (wraz z Kozakami?), przy czym w samej bitwie uczestniczyło jedynie ok. 15-16 tys. żołnierzy szwedzkich, zob. P. From: Klęska pod Połtawą..., s. 317-318; W.A. Serczy к: Piotr I Wielki..., s. 139. O wzajemnych kontaktach Karola XII i Iwana Mazepy tak pisze Bengt LiLjegren (Karol XII..., s. 167): „Stary hetman mówił po łacinie i był znakomitym kompanem do zabaw, zrobił więc na Karolu dobre wrażenie". 
A.D. Mieńszykow dostał się do niewoli. Informację tę podano w gazecie pisanej przeznaczonej dla podkanclerzego Stanisława Antoniego Szczuki. Redaktor zachował jednak niezbędną ostrożność, zaznaczając na końcu: „Ale że nic o tym nie masz z obozu szwedzkiego, trzeba się kontentować samym odgłosem, a czekać konfirmacji” ${ }^{37}$.

Pierwsze wzmianki o faktycznej bitwie pod Połtawą, do której doszło 8 lipca 1709 roku, dotarły do obozu Stanisława Leszczyńskiego 18 lipca tegoż roku. Najpierw pewien szlachcic przysłał informację, „że między Moskwą wielka jakaś skryta jest konsternacja, gdyż między niemi samemi odgłos ten, że król szwedzki wielki temi czasami miał mieć awantaż [sukces] nad Moskwą w Ukrainie”, w związku z czym hetman A. Sieniawski wysłał tam kogoś, by sprawdzić te pogłoski. Jednocześnie tego samego dnia doszedł do króla Stanisława list z wiadomością, „że w obozie kwarcianym i moskiewskim w przeszłą niedzielę [14 lipca 1709] miano triumfować z otrzymanej niby cara nad Szwedami w Ukrainie wiktorii”. Ostrożny J.M. Karp dodał zastrzeżenie: „o czym konfirmacja potrzebna”. Cztery dni później, 22 lipca, z Krakowa i z obozu hetmana A. Sieniawskiego, skąd przybyło 2 oficerów, przyszły jednak doniesienia potwierdzające sukces wojsk rosyjskich. Okazało się, „że w przeszły poniedziałek to jest d. 15 p[rae]sen[tis] [lipca] w obozie kwarcianym triumfowano strasznie z otrzymanej niby pod Pułtawą [Połtawą] nad królem szwedzkim batalii, w której i wojsko szwedzkie ad internecium [do szczętu] zniesione, i sam król szwedzki z[abi]ty, a Reinszeld [Karl Gustav Rehnskiöld] i [Karl] Piper w niewolę wzięci”. J.M. Karp zaznaczył przy tym, iż „tego konfirmacja potrzebna, bo Moskwie nie nowina i przegrawszy przypisywać sobie wiktorię". Wyraził też wątpliwość co do wiarygodności tych informacji, gdyż listy Piotra I spod Połtawy do hetmana Adama Sieniawskiego i do rosyjskiego feldmarszałka Henryka Goltza (Golcza) datowane są 8 i 9 lipca, a w obu jest zaś mowa, że wysyła się je w dzień bitwy. Sekretarz królewski zauważył jednak, iż może to też świadczyć o tym, że batalia ta trwała kilka dni ${ }^{38}$.

25 lipca 1709 roku wydawało się, że wszelkie wątpliwości zostały rozwiane. Wówczas to „przyszła do Króla JM [Stanisława] i ze Lwowa, i z obozu kwarcianego wiadomość, że ten list carski [Piotra I do Adama Sieniawskiego] wcale jest zmyślony, owszem to zapewnie oznajmują, że $60 \mathrm{~m}$. [tysięcy] Moskwy zginęło, a król szwedzki [Karol XII] wiktorię otrzymał". Podobno hetmanowa Elżbieta Sieniawska „sama żartowała z tego listu carskiego i narzekała na pryncypałów [przywódców konfederacji sandomierskiej], że śmiech z siebie czynią; pisano o tym ze Lwowa”. Piotr I miał w związku z tą klęską odwołać feldmarszałka H. Goltza

\footnotetext{
37 AGAD, Archiwum Publiczne Potockich (dalej: APP), t. 162/2, Gazeta pisana, W obozie pod Szczucinem 26 VI 1709.

${ }^{38}$ AGAD, AR, dz. V, t. 6465/V, s. 262-263, J.M. Karp do K.S. Radziwiłła, Pod Bolesławem 25 VII 1709.
} 
z Wołynia na Ukrainę. Według tych informacji zarówno dowódcy wojsk polskich, A. Sieniawski oraz Hrehory Ogiński, jak i feldmarszałek H. Goltz wysłali specjalnych kurierów w kierunku Ukrainy, pragnąc dowiedzieć się, co tam właściwie się stało $^{39}$.

Radość w obozie króla Stanisława trwała jednak krótko. Już dwa dni później, 27 lipca, marszałek nadworny koronny Stanisław Tarło powiadomił monarchę, „że widział się z pewnym księdzem z obozu kwarcianego jadącym, iż tam przyszła konfirmacja o wiktorii cara i że króla szwedzkiego znaleziono między trupami zabitego". Doniósł też, że przeciwnicy Leszczyńskiego mają opublikować manifest powiadamiający wszystkich o tej klęsce Szwedów ${ }^{40}$. Następnego dnia przyjechał poseł francuski Jean Louis Bonnac, który uprzednio próbował mediować między królem Stanisławem a hetmanem A. Sieniawskim. Przywiózł on list pisany przez A. Sieniawskiego potwierdzający zwycięstwo Piotra I pod Połtawą. Tegoż dnia nadeszło zresztą kilka innych relacji o całkowitej klęsce Karola XII, który postrzelony w nogę, z trzema tylko tysiącami żołnierzy uratował się „przez błota”. I. Mazepa miał wraz z Kozakami wycofać się. J.M. Karp zaznaczył jednak, że „tu zaś póty wierzyć temu nie chcą, aż przybędzie o tym wiadomość od samego króla szwedzkiego" $^{41}$.

Następnego dnia, 29 lipca, sekretarz królewski pisał, że w otoczeniu króla Stanisława podejrzewa się posła francuskiego J.L. Bonnaca o jakieś machinacje „przeciwko interesom królewskim", gdyż sam monarcha skarżył się na niego przed podkanclerzem litewskim Stanisławem Antonim Szczuką. Wygląda więc, że nie w pełni ufano informacjom J.L. Bonnaca o zwycięstwie Rosjan. J.M. Karp zaznaczył, iż choć tu nie wierzą w przegraną Karola XII, to jednak sam monarcha i gen. E.D. Krassow obawiają się skutków ewentualnej klęski Szwedów. Była to pierwsza wzmianka sekretarza królewskiego o zaniepokojeniu w kręgach prostanisławowskich polityków i szwedzkiego dowództwa, jakie wywołały pogłoski o niepomyślnym wyniku bitwy połtawskiej. Najbardziej charakterystyczne jest jednak przy tym stwierdzenie J.M. Karpia, iż „Polacy zaś wszyscy tu będący życzą, żeby o zabiciu króla szwedzkiego nie odmieniło się, dla prędszego w Polszcze pokoju, bo choć i w sto koni będzie się salwował król szwedzki, to prędkiego nie spodziewać się uspokoje-

${ }^{39}$ Ibidem, s. 269, J.M. Karp do K.S. Radziwiłła, Pod Bolesławem 25 VII 1709.

${ }^{40}$ Ibidem, s. 275, J.M. Karp do K.S. Radziwiłła, Pod Bolesławem 29 VII 1709. Dnia 25 lipca 1709 roku do obozu hetmana Adama Sieniawskiego przybył hetmański rezydent przy boku Piotra I płk Józef Tausz, który był naocznym świadkiem bitwy połtawskiej. Uniwersał Sieniawskiego wzywający do dalszej walki został ogłoszony 29 lipca, zob. J.A. Gierowski: W cieniu Ligi Północnej. Wrocław 1971, s. 82.

${ }^{41}$ Ibidem, s. 276-277, J.M. Karp do K.S. Radziwiłła, Pod Bolesławem 29 VII 1709. Hetman Adam Sieniawski po otrzymaniu listu Piotra I spod Połtawy natychmiast rozesłał wiadomości o tym zwycięstwie Rosjan, zob. J.A. Gierowski: W cieniu Ligi Północnej..., s. 82 . 
nia"42. Nic nie mogło lepiej oddać rzeczywistych uczuć polskich stronników Stanisława Leszczyńskiego do ich szwedzkiego protektora ${ }^{43}$.

Niezadowolenie króla Stanisława $\mathrm{z}$ faktu rozgłaszania przez francuskiego dyplomatę J.L. Bonnaca wiadomości o klęsce Karola XII potwierdza późniejsza anonimowa relacja zachowana $\mathrm{w}$ archiwum drezdeńskim i opublikowana $\mathrm{w}$ polskim tłumaczeniu przez Edwarda Raczyńskiego. Jej autorem przypuszczalnie był sekretarz królewski, a zarazem tajny agent saski Gottlieb Biber. Pisał on, że pierwsza wiadomość o bitwie połtawskiej dotarła do obozu króla Stanisława pod Bolesławem, pojawiły się też i drukowane opisy tej zwycięskiej dla Rosjan batalii, „ale temu wierzyć nie chciano tak dalece, że Król Stanisław mocno strofował markiza de Bonac o to, że niepomyślne rozgłaszał nowiny. Robiono nawet znaczne zakłady, że ta wiadomość zupełnie była fałszywą"44.

Po wycofaniu się króla Stanisława do Opatowca nad Wisłą dotarło tam kilka kolejnych informacji, które wcale jednak nie wyjaśniły sytuacji. Dnia 1 sierpnia 1709 roku J.M. Karp pisał, że z kilku przechwyconych listów przeciwników Leszczyńskiego wynikałoby, że klęska Szwedów nie jest wcale taka wielka, żołnierzy szwedzkich miało bowiem zginąć w tej batalii tylko 2 tys., podczas gdy Rosjanie stracić mieli aż 30 tys. ludzi. Królewski sekretarz zastrzegał się przy tym, że „w rzeczy zaś samej absolute pewnej relacji żadnej dotąd nie masz o tej akcji”. Co więcej, przybyły wówczas goniec ze Zbaraża „przyniósł nowinę affirmando pro certo [potwierdzającą jako pewną] o wygranej króla JM szwedzkiego, cum hac particularitate [z tym szczegółem], że 60 dział wziął Moskwie i że po tej wygranej obrócił się prze[ciw]ko temu wojsku moskiewskiemu, które szło od Kijowa"45. Z tej też okazji marszałek nadworny koronny Stanisław Tarło „wielką dał ucztę, na której wszyscy licznie spełniali puchary za zdrowie mniemanych zwycięzców"46.

W tym samym czasie w obozie pod Opatowcem krążyły jednak i inne informacje potwierdzające zdecydowany sukces cara Piotra I. W zredagowanej tam wówczas gazecie pisanej czytamy: „Zwycięstwo moskiewskie pod Pułtawą d. 8 Iulii otrzymane, bez przestanku głoszą tu i rozpisują z różnymi coraz konfirmacjami i przydatkami, między którymi i to już jest, że Króla JM szwedzkiego samego między trupami znaleziono". Ostrożny redaktor przejawiał jednak przy tym, podobnie jak

${ }^{42}$ AGAD, AR, dz. V, t. 6460, s. 44-45, J.M. Karp do K.S. Radziwiłła, Pod Bolesławem 29 VII 1709.

${ }^{43}$ Zwrócił już na to uwagę, przytaczając ten cytat z listu J.M. Karpia, J.A. Gierowski: W cieniu Ligi Północnej..., s. 84.

${ }_{44}$ Materyały do historii Stanisława Leszczyńskiego króla polskiego. Wyd. E. RaCzyński. Poznań 1841, s. 25 (Obraz Polaków i Polski w XVIII wieku..., t. 13). O Gottliebie Biberze zob. M. Durbas: Sekretarz króla Stanisława - agent czy wierny sługa. W: Władza i polityka w czasach nowożytnych. Red. Z. ANusik. Łódź 2011, s. 17-34.

${ }_{45}$ AGAD, AR, dz. V, t. 6465/VI, s. 7-8, J.M. Karp do K.S. Radziwiłła, Opatowiec 1 VIII 1709.

${ }^{46}$ Materyaly do historii Stanisława Leszczyńskiego..., s. 26. 
i wielu innych obecnych tam ludzi z dworu króla Stanisława, dość wyraźny sceptycyzm: „W mocy Boskiej nie masz nic niepodobnego, Który sam zwycięstwa daje. Że jednak te relacje coraz to różne i insze przynoszą cyrkumstancje, nikt im dotąd doskonale wierzyć nie chce, ile kiedy i przedtym bez przestanku pisano, że Szwedów biją, [...] a po staremu prawda inaczej potym otworzyła oczy i teraz niepodobna, żeby się ta prędko wyjawić nie miała" ${ }^{47}$.

Dwa dni później, 3 sierpnia, do Opatowca napłynęły trzy kolejne, całkowicie sprzeczne relacje. Pochodziły one od specjalnych wysłanników, których hetman wielki koronny A. Sieniawski na pierwszą wiadomość o klęsce Szwedów wyprawił na Ukrainę, „dla wywiedzenia się tam co się właśnie stało”. Jeden z nich miał przynieść wiadomość, że w bitwie, którą stoczono 8 lipca, „wszystka kawaleria moskiewska zginęła, lecz Szwedów tak poparto, że z resztą król JM szwedzki i z Kozakami przy Mazepie będącemi, musiał się rejterować w granice tureckie i wołoskie". Ma stamtąd próbować przedostać się do Polski, w związku z czym hetman A. Sieniawski miał zaraz wysłać 30 chorągwi jazdy „ku granicom wołoskim, dla obserwowania marszu szwedzkiego i jeśli poda się okazja infestowania [atakowania] onych [Szwedów]”. Według relacji drugiego hetmańskiego wysłannika, pod Połtawą „,naprzód $70 \mathrm{~m}$. [tysięcy] Moskwy dało batalię Szwedom. Szwedzi te $70 \mathrm{~m}$. [tysięcy] ad internecionem [doszczętnie] znieśli, lecz jako supervenere [przybyło] drugie $70 \mathrm{~m}$. [tysięcy] świeże, Szwedzi przełamani zostali i z pola ustąpić musieli”. Natomiast jak pisze J.M. Karp, była też „trzecia relacja, której tu najbardziej wierzą [...], że naprzód $6 \mathrm{~m}$. [tysięcy] Szwedów i 20 m. [tysięcy] Kozaków biło się z Moskwą, lecz Moskwa dla złej kointeligencji [współpracy] Szwedów z Kozakami (bo Szwedzi bili się, a Kozacy tylko na to patrzali nie dopomagając onym) zniosła tę partię, za nastąpieniem zaś całego wojska szwedzkiego, Moskwa funditus [całkowicie] jest zniesiona"48.

Przekonanie, że bitwa połtawska wcale nie zakończyła się klęską Szwedów, mogły podtrzymać opowieści jakiegoś księdza, który przyjechał 7 sierpnia 1709 roku do Opatowca ze Lwowa. Twierdził on, że we Lwowie pełno jest informacji pomniejszających zwycięstwo rosyjskie lub nawet uważających tę informację „za zmyśloną"49.

Wydawać by się mogło, że szczegółowe wiadomości, które napłynęły do Opatowca 15 sierpnia 1709 roku, ostatecznie wyjaśniły rzeczywisty wynik bitwy pod Połtawą. Na ich podstawie twierdzono, że tuż przed batalią car Piotr I zaoferował królowi szwedzkiemu zawarcie traktatu pokojowego. Karol XII podobno się nawet do tego skłaniał, ale miał mu to odradzić jego minister Karl Piper. Dlatego też po

${ }^{47}$ AGAD, APP, t. 162/2, Gazeta pisana, W obozie pod Opatowcem 1 VIII 1709.

48 AGAD, AR, dz. V, t. 6465/VI, s. 12-14, J.M. Karp do K.S. Radziwiłła, Opatowiec 4 VIII 1709. Kozacy praktycznie nie wzięli udziału w bitwie połtawskiej, gdyż Karol XII przeznaczył ich do ochrony taborów, P. From: Klęska pod Połtawą..., s. 317.

49 AGAD, AR, dz. V, t. 6465/VI, s. 245, J.M. Karp do K.S. Radziwiłła, Opatowiec [po 7 VIII 1709]. 
bitwie Szwedzi, którzy wraz z K. Piperem dostali się do niewoli rosyjskiej mieli go obwiniać o przyczynienie się do klęski. Także oficerowie szwedzcy obecni przy królu Stanisławie byli „źli o toż na Pipera, wróżąc mu szubienicę et confiscationem wszystkiej substancji”. Po ucieczce z pola bitwy zwołać miał Karol XII radę wojenną, na której Iwan Mazepa radził, żeby król przede wszystkim zadbał o swoje bezpieczeństwo. „Akceptował tę radę król szwedzki i w tysiącu tylko koni, skrytemi drogami, któremi Tatarzowie [Tatarzy] Mazepę prowadzili przebrał się do Benderu, stąd Wołochami i Węgrami przebierać się miał [do Polski]. Wojsku zaś swemu plenariam [pełną] dał facultatem [swobodę], żeby to czyniło, co będzie się zdało. I tak gdy przez trzy dni chleba nie było, poddać się musieli”. Zdaniem J.M. Karpia, przebywający w Opatowcu Szwedzi wierzą tej relacji, choć wątpią w niektóre szczegóły ${ }^{50}$. Następnego dnia do Stanisława Leszczyńskiego dotarła jednak wiadomość, ,jakoby król szwedzki [Karol XII] miał jakiś dezawantaż [niepowodzenie] pod Pułtawą [Połtawą], ale potym wziął Pułtawę i Moskwę na głowę zniósł”. Do tego wszystkiego jakiś ułan z wojska koronnego hetmana A. Sieniawskiego spotkawszy się z którymś z żołnierzy króla Stanisława, miał mu powiedzieć: „Wasze rzeczy dobrze idą, nie słuchajcie tego, co piszą i powiadają". J.M. Karp niezależnie od tych pomyślnych dla Szwedów wiadomości doniósł także, że według krążących naokoło informacji Karol XII znajduje się już na Węgrzech. Dodał przy tym, iż po cichu się mówi, że król Stanisław zamyśla odłączyć się od szwedzkiej eskorty i udać się do oddziałów wojewody kijowskiego Józefa Potockiego ${ }^{51}$.

Wiadomości o tych nastrojach w najbliższym otoczeniu Leszczyńskiego musiały dotrzeć i do księcia Janusza Wiśniowieckiego, który wprawdzie wówczas nie był obecny w Opatowcu, ale w swym dzienniku zanotował: „Długo Polska na takie nowiny [o klęsce połtawskiej] wiary nie dawała, i lubo przychodziły różne wiadomości, przecie dwór stanisławowski dobrze sobie rokował" ${ }^{52}$. Podobne informacje o złudzeniach króla Stanisława doszły i do starosty mińskiego Krzysztofa Zawiszy, który przebywał u boku hetmana wielkiego litewskiego Jana Kazimierza Sapiehy. W swym pamiętniku K. Zawisza napisał: „Król imć Stanisław długo nie wierzył tej rewolucji, jakoż zwycięstwo [Piotra I] przewyższało wiarę i bardziej przez cud niż męstwem miane" ${ }^{\mathrm{W} 3}$.

${ }^{50}$ Ibidem, s. 23-25, J.M. Karp do K.S. Radziwiłła, Opatowiec 16 VIII 1709. Już podczas oblężenia Połtawy Rosjanie, pod pretekstem wymiany jeńców, podjęli próby kontaktów ze Szwedami, sugerując możliwość zawarcia pokoju pod warunkiem pozostawienia przy Rosji Petersburga i Ingrii, co jednak nie spotkało się z odzewem ze strony Karola XIII, zob. P. From: Klęska pod Połtawa..., s. 295.

${ }^{51}$ AGAD, AR, dz. V, t. 6465/VI, s. 77-78, J.M. Karp do K.S. Radziwiłła, Opatowiec 17 VIII 1709.

52 J.A. Wiśniowiecki: Ilias Polski (1700-1710). Wyd. P.P. Romaniuk, J. BuRdowicz-Nowicki. Warszawa 2018, s. 257.

${ }^{53}$ K. Zawisza: Pamiętniki Krzysztofa Zawiszy, wojewody mińskiego (1666-1721). Wyd. J. BARToszewiCz. Warszawa 1862, s. 273. 
Dopiero 18 sierpnia 1709 roku otrzymał Stanisław Leszczyński autentyczne informacje o bitwie połtawskiej i o dalszych losach króla szwedzkiego. Tegoż dnia przyjechał do Opatowca Brodzicki, kurier wysłany 21 lipca przez Karola XII z tureckiego Benderu. Potwierdził on wszystkie informacje o klęsce Szwedów, przy czym, jak zauważył J.M. Karp, jego relacja niezbyt różniła się od wcześniejszych doniesień rosyjskich. Sam Brodzicki uczestniczył w bitwie połtawskiej, sporą część wydarzeń znał więc $\mathrm{z}$ autopsji. Mówił:

że król szwedzki nie spodziewając się, żeby cała potencja moskiewska miała stanąć pod Pułtawą, z piechotami i 4 [regimentami] tylko kawalerii d. 8 Iulii [lipca] ruszył się równo z świtem prz[eciw]ko Moskwie, której było ze $20 \mathrm{~m}$. [tysięcy], tę tedy złamał i gonił aż do samych okopowań, chcąc onych dobyć, lecz tam był Szeremet [Borys Piotrowicz Szeremietiew] ze $60 \mathrm{~m}$. [tysięcy] najwyborniejszego ludu i tak dobry dał odpór, że się Szwedzi zmieszali i tył poddali, rejterując się ku taborom, gdzie wszystka kawaleria, oprócz tych 4 regimentów, które w batalii zginęły, była i artyleria wszystka $\mathrm{z}$ amunicjami. W tej batalii kilka regimentów pieszych szwedzkich rzucili broń o ziemię i poddali się. [...] W batalii było $16 \mathrm{~m}$. [tysięcy] Zaporożców, którzy ni razu nie strzeliwszy, zdali [poddali] się.

Bitwa miała trwać od godziny 4 „z rana” aż do godziny 11 w południe. W dalszej części swej opowieści Brodzicki dodał, iż „królowi szwedzkiemu w batalii dwóch koni pod noszami zabito i nosze ustrzelono". Klęskę Szwedzi przypisywali głównie temu, „że sam król dla postrzału swego nie mógł wojskiem komenderować”. Po przegranej bitwie „uchodził tedy dniem i nocą król szwedzki aż do Perewołoczny [wsi przy ujściu Worskli do Dniepru], którego z razu Moskwa nie goniła, obawiając się zasadzki, aż dopiero jak dał znać pewny Kozak, że Szwedzi rejterują się, wysłano za nimi pogoń". Według tej relacji Brodzickiego pod Perewołoczną zaraz odbyła się rada wojenna, na której gen. A.L. Lewenhaupt i hetman I. Mazepa na wszystkie świętości zaklinali króla, żeby zadbał o bezpieczeństwo swojej osoby, gdyż chciał zostać przy taborach i bronić się. Ponieważ był ranny (postrzelony w nogę), ustąpił „i tak kilka czajek [łodzi] związawszy, przeprawiono na nich króla”. A.L. Lewenhaupt obiecał przy tym królowi, że z pozostałą armią szwedzką przez tydzień będzie bronić się przed Rosjanami, by dać monarsze czas potrzebny na dotarcie do Turcji. Karol XII podobno i tak był w niebezpieczeństwie, bowiem gen. Grigorij Siemionowicz książę Wołkoński udał się w pogoń za szwedzkim monarchą i naprzeciw Oczakowa, tureckiej twierdzy po drugiej stronie Dniepru, gdzie Szwedzi czekali na zgodę Turków na przejście granicy, „urwał coś gromady asystującej króla szwedzkiego i gdyby nie dobry kałauż [przewodnik] tatarski [...], pewnie sam król wpadłby był w ręce pomienionego księcia Wołkońskiego". Niektórzy Szwedzi próbujący uciec na stronę turecką, ,jakim kto mógł sposobem przeprawowali się, a najbardziej 
wpław na koniach oklep, bo dla szerokości haniebnej Dniepru niepodobna było na okulbaczonym koniu przepłynąc" ${ }^{54}$.

Opis bitwy pod Połtawą i ucieczki Karola XII do Turcji przedstawiony przez Brodzickiego w znacznej mierze odpowiada prawdzie. W pierwszym etapie batalii, która rzeczywiście zaczęła się 8 lipca 1709 roku, jeszcze przed wschodem słońca armia szwedzka podjęła próbę ataku z zaskoczenia na obóz rosyjski. Rosjanie przywitali ich jednak ogniem $z$ dział i karabinów. Na skutek niedostatecznego rozpoznania Szwedzi nie zdawali sobie sprawy, że przed właściwym obozem ciągnie się szereg nowo wzniesionych szańców (redut). Mimo to część z tych obwarowań udało im się zdobyć, co więcej - odparli atak kawalerii rosyjskiej. Prawe skrzydło szwedzkiej piechoty podjęło nawet szturm na właściwy obóz i Piotr I rozważał ewentualność wycofania swej armii na drugi brzeg Worskli. Wtedy jednak okazało się, że część piechoty szwedzkiej, bezskutecznie próbująca zdobyć pozostałe reduty, pod silnym ogniem przeciwnika wycofała się do pobliskiego lasu. Faktycznie dowodzący armią szwedzką feldmarszałek K.G. Rehnskiöld (król Karol XII był ranny) wstrzymał natarcie, chcąc uporządkować szyki. Wykorzystał to Piotr I, wyprowadzając całą swoją piechotę w pole. Doszło do bezpośredniego starcia głównych sił obu armii. Na prawym skrzydle Szwedzi odnieśli wprawdzie drobne sukcesy, ale całe lewe skrzydło szwedzkiej piechoty załamało się i żołnierze w panice zaczęli uciekać. Bitwa była $\mathrm{w}$ tym momencie, to jest ok. godziny $11 \mathrm{w}$ południe, praktycznie już przegrana. Resztki szwedzkich oddziałów zdołały wycofać się do taborów. W bitwie zginęło przeszło 6 tys. żołnierzy szwedzkich, a blisko 3 tys. dostało się do niewoli. Wieczorem Szwedzi rozpoczęli odwrót na południe. Przy Karolu XII zostało ok. 10 tys. zdolnych do walki żołnierzy szwedzkich (w tym ludzie eskortujący tabory i niebiorące udziału w walce oddziały blokujące Połtawę), blisko 3 tys. Kozaków oraz przeszło 5 tys. rannych. Większość tej armii, nie mogąc pod Perewołoczną przeprawić się na drugi brzeg Dniepru, poddała się 12 lipca 1709 roku Rosjanom ${ }^{55}$.

Dalsza część relacji Brodzickiego dotyczyła już wydarzeń w Turcji. Karol XII miał przybyć do Benderu z 1,2 tys. ludzi - „Szwedów, Polaków, Kozaków i Wołochów, między któremi najmniej liczy się Szwedów”. Warto zresztą przytoczyć tu dłuższy cytat z opowieści Brodzickiego, który był naocznym świadkiem tego, co się działo na granicy tureckiej po przybyciu tam uciekinierów spod Połtawy:

Wielka tam zrazu była drożyzna, bo co u nas za grosz [1/30 złp] kupią, to tam płacono po czerwonemu złotemu [18 złp] za taki kawałek suchara

${ }^{54}$ AGAD, AR, dz. V, t. 6465/VI, s. 33-36, 39, J.M. Karp do K.S. Radziwiłła, Opatowiec 20 VIII 1709. Zob. też Materyały do historii Stanisława Leszczyńskiego..., s. 26. O tej relacji Brodzickiego pisze też skrótowo J.A. Gierowski: W cieniu Ligi Północnej..., s. 84-85.

${ }_{55}$ L.G. Beskrovnyj: Strategiâ i taktika russkoj armii v Poltavskij..., s. 51-59; P. From: Klęska pod Poltawa..., s. 303-401; W.A. Serczy K: Poltawa 1709..., s. 128-137; Z. Anusik: Karol XII..., s. $239-279$. 
i to dobijano się do kupna. Szwedzi szpadami odganiali Polaków od tego miejsca, gdzie suchary przedawano, co postrzegłszy Turcy Szwedów odganiali, a Polaków przypuszczali. Jakoż i przedtym, nad którąś rzeką (ile ich 3 przebywał król szwedzki) wypływających Polaków i Wołochów przyjmowali Turcy, bracią swoją nazywając i suchary darmo dawali, a ze Szwedów urągali się, że uciekają, zowiąc ich sobakami. Seraskier [Hadżi Yusuf] cum omni magnificentia [ze wszelką wspaniałością] przyjął króla szwedzkiego i zaraz dwadzieścia tysięcy janczarów sprowadził pro securitate [dla bezpieczeństwa] osoby jego. Król szwedzki w polu pod namiotami stoi. Ex principalibus [z dostojników] przy nim tylko Lagierkron [Anders Lagercrona], Spar [Axel Sparre] dwa razy postrzelony, generałowie i pułkownik drabański Holl [Axel Hård]. JMP [Stanisław] Poniatowski ministrum [ministerstwo] teraz supremum agit [najwyższe sprawuje] u króla szwedzkiego, bo wszystkie osoby do kancelarii należące albo zaginęły, albo w niewolę wzięte ${ }^{56}$.

Brodzicki opowiadał ponadto o ówczesnej sytuacji politycznej, o postawie Turcji i o nadziejach Karola XII na szybką odbudowę swej potęgi militarnej. J.M. Karp był jednak bardzo sceptyczny wobec tych rewelacji, komentując to w swoim liście: „powiadał i o innych rzeczach tenże umyślny [Brodzicki], ale mniej to do wiary podobnych". Brodzicki m.in. zapewniał, że 50 tys. Tatarów stanęło do pomocy królowi szwedzkiemu, że już trzy razy wpadali w granice rosyjskie, biorąc jasyr, że Turcja odrzuciła żądania Rosji usunięcia Karola XII ze swego terytorium, a co więcej zapowiedziała, iż udzieli mu pomocy wojskowej i w tym celu potężnie się zbroi. Do tego dodał, „że car po batalii przysłał do króla szwedzkiego, prosząc o pokój, ale król szwedzki taki miał dać respons, że car niech nie rozumie, żebym tak bardzo przyciśniony był do uczynienia z nim pokoju przez teraźniejszą przegrane, niech wszem to wie, że na Boże Narodzenie sto tysięcy wojska wystawię prz[eciw]ko niemu"57.

Tymczasem w końcu sierpnia 1709 roku podczas pobytu króla Stanisława pod Koprzywnicą (na południe od Sandomierza) dotarła tam wiadomość, iż wojska saskie stanęły nad Odrą, co oznaczałoby zapowiedź powrotu Augusta II do Rzeczypospolitej. Znacznie pomyślniejszą informację przysłał z Podola 29 sierpnia Samuel Górski, były wysłannik Leszczyńskiego do Konstantynopola. Pisał on,

że Turcy [...] wypowiedzieli wojnę Moskwie i że Porta daje pod komendę króla szwedzkiego czterdzieści tysięcy jazdy i dwadzieścia pięć tysięcy janczarów. Kazała także dwóm chanom w sto tysięcy i więcej Ordy goto-

\footnotetext{
${ }^{56}$ AGAD, AR, dz. V, t. 6465/VI, s. 36-38, J.M. Karp do K.S. Radziwiłła, Opatowiec 20 VIII 1709.

${ }^{57}$ Ibidem, s. 40-42, J.M. Karp do K.S. Radziwiłła, Opatowiec 20 VIII 1709.
} 
wać się in assistentiam [na wsparcie] królowi szwedzkiemu. Nie powracając tedy już do Polskiey, prosto z temi wojskami król szwedzki ma pójść prze[ciw]ko Moskwie.

Jozafat Michał Karp złośliwie zauważył, iż „w tę nowinę jak w ewangelię uwierzyli nasi tu Szwedzi et demonstrat [i okazują] stąd wielkie ukontentowania, millenis laudibus [tysiącami pochwał] Portę efferendo [sławiąc]". Przejawiał przy tym, podobnie jak inne osoby z otoczenia królewskiego, znamienną nieufność, dodając, że „Polacy zaś ad primum nuntium [na pierwszą wiadomość] nie chcą temu wierzyć, czekają na konfirmację"58.

Sceptycyzm J.M. Karpia był, przynajmniej w tym momencie, w pełni uzasadniony. Turcja udzieliła wprawdzie schronienia Karolowi XII i resztkom jego armii, ale nie zamierzała wówczas rozpoczynać wojny ze zwycięskim Piotrem I, co więcej, na przełomie 1709/1710 roku doszło do odnowienia rosyjsko-tureckich traktatów pokojowych. Ultymatywne domaganie się przez Piotra I wydalenia Karola XII, pod groźbą rozpoczęcia wojny z Turcją, doprowadziło jednak w końcu 1710 roku do zasadniczej zmiany w stanowisku Państwa Ottomańskiego, które zdecydowało się na rozpoczęcie działań zbrojnych ${ }^{59}$.

Stanisław Leszczyński wraz ze swymi stronnikami (liczba ich szybko malała) i z eskortującym go korpusem szwedzkim gen. E.D. Krassowa, obawiając się zbliżających się ze wschodu wojsk rosyjskich oraz oddziałów koronnych hetmana A. Sieniawskiego, wycofywał się w kierunku Kielc. W pobliżu tego miasta, w Łagowie u podnóża Gór Świętokrzyskich, nastąpiło 2 września 1709 roku dawno oczekiwane spotkanie z powoli ciągnącymi z Pomorza Szwedzkiego regimentami szwedzkiej piechoty. Szwedzi nie mieli już żadnych wątpliwości dotyczących wyniku bitwy pod Połtawą. Składali sobie nawzajem kondolencje w związku ze śmiercią krewnych i znajomych. Jednomyślnie winą za tę bezprzykładną klęskę obciążali Karola XII, mówiąc: „Nasz król wszystko coś chciał czynić nie po ludzku”. Przypominali przy tym równie zuchwałe działania Karola XII w bitwie z Sasami pod Poniecem w 1704 roku, „gdzie similiter [podobnie] nie strzelając, szpadami chciał w kilku regimentach swoich, kilkanaście regimentów saskiej piechoty, lecz cum dedecore [z niesławą] musiał cofnąć się, straciwszy więcej tysiąca swoich ludzi”"60. Bitwa ta praktycznie była nierozstrzygnięta, Szwedzi ponieśli znaczne straty, a Sasi nie zostali rozbici, lecz wycofali się, zachowując zdolność do dalszej walki ${ }^{61}$.

\footnotetext{
${ }^{58}$ Ibidem, t. 6465/V, s. 132-133, J.M. Karp do K.S. Radziwiłła, Pod Koprzywnicą 31 VIII 1709; zob. też ten cytat u J.A. Gierowskiego: W cieniu Ligi Pólnocnej..., s. 84.

${ }^{59}$ Zob. Z. Anusik: Karol XII..., s. 284-291; W.A. SercZY K: Piotr I Wielki..., s. 145-148.

${ }^{60}$ AGAD, AR, dz. V, t. 6465/VI, s. 46, J.M. Karp do K.S. Radziwiłła, Kozłów 8 IX 1709.

${ }^{61}$ D. PŁowy: Poniec 7 XI 1704. Kampania jesienna Karola XII. Tarnowskie Góry 2013. Zarzut ten był słuszny, gdyż podczas bitwy pod Połtawą Karol XII pozostawił prawie całą swoją artylerię przy taborach, zob. P. From: Klęska pod Połtawą..., s. 309, 331-333.
} 
Ponieważ potwierdziły się wiadomości o wkroczeniu do Polski Augusta II z wojskiem saskim, 2 września w Łagowie odbyła się narada wojenna oficerów szwedzkich z udziałem króla Stanisława. Ponieważ siły saskie miały nie przekraczać 5 tys. żołnierzy, postanowiono połączyć wszystkie znajdujące się w Rzeczypospolitej jednostki szwedzkie oraz wojsko litewskie hetmana Jana Kazimierza Sapiehy i uderzyć na Sasów. Stanisław Leszczyński sugerował nawet, by powtórzyć manewr Karola XII z 1706 roku i wkroczyć do Saksonii. Zdecydowano się wówczas skierować $\mathrm{w}$ stronę Wielkopolski ${ }^{62}$. Ostatecznie jednak nie zrealizowano tego planu, słusznie obawiając się otoczenia przez połączone siły saskie (liczyły faktycznie 11 tys. żołnierzy), rosyjskie i wojska koronne hetmana A. Sieniawskiego. Oddziały szwedzkie, wraz z królem Stanisławem i nielicznymi jego stronnikami, przeszły więc przez Wielkopolskę i 13 października 1709 roku opuściły granice Rzeczypospolitej, znajdując schronienie dopiero na Pomorzu Szwedzkim ${ }^{63}$.

Nie ulega wątpliwości, że Stanisław Leszczyński i jego najbliższe otoczenie żyło w przekonaniu o geniuszu militarnym Karola XII i o niezwyciężoności jego wojsk. Inna rzecz, iż po szwedzkich zwycięstwach nad Piotrem I, wyeliminowaniu Danii z wojny północnej, sukcesach w Polsce, wreszcie zajęciu Saksonii i zmuszeniu do abdykacji Augusta II przekonanie to podzielała prawie cała Europa. Nic też dziwnego, że pierwsze wiadomości o pochodzie Karola XII w głąb Rosji latem 1708 roku i o zwycięskich bitwach przyjmowano na dworze Leszczyńskiego jako rzecz oczywistą. Raczej nie zdawano sobie sprawy, że napływające ze wschodu doniesienia są stronnicze. Wyraźnie wyolbrzymiały one szwedzkie sukcesy, drobne potyczki zamieniając $w$ wielkie bitwy i zwiększając nieustannie liczbę zabitych żołnierzy rosyjskich. W świetle informacji napływających od sierpnia 1708 roku do początku lipca 1709 roku Rosjanie mieli stracić aż 102 tys. ludzi, choć według innych doniesień straty te wynosić miały odpowiednio: 82, 62 lub 75 tys. żołnierzy. Najbardziej wiarygodne wydawały się dane zawarte w listach jednego z najbliższych ludzi Karola XII, płk. Stanisława Poniatowskiego, który na przełomie marca i kwietnia 1709 roku pisał, że Rosjanie od momentu wejścia Szwedów stracili 60 tys. żołnierzy. W otoczeniu króla Stanisława, ale też i w dowództwie sił szwedzkich stacjonujących w Polsce nie dostrzegano, że wciąż nie doszło do zasadniczej bitwy, a główne siły rosyjskie nie zostały rozbite. Nie zdawano sobie też sprawy, że decyzja Karola XII skierowania się na południową Ukrainę wynikała z niemożności dalszego posuwa-

${ }^{62}$ AGAD, AR, dz. V, t. 6465/VI, s. 45-46, J.M. Karp do K.S. Radziwiłła, Kozłów 8 IX 1709. O tym planie króla Stanisława pisał też anonimowy autor (Gottlieb Biber?) relacji z archiwum drezdeńskiego, z wyraźną przesadą obliczając łączne siły Szwedów i wojsk podległych Leszczyńskiemu na 47 tys. (zob. Materyały do historii Stanisława Leszczyńskiego..., s. 27-28). W rzeczywistości gen. Ernst Detlof Krassow miał do dyspozycji co najwyżej kilkanaście tysięcy żołnierzy, tak Szwedów, jak i Polaków.

${ }_{63}$ E. Cieśla : Stanisław Leszczyński..., s. 62; J.A. Gierowski: W cieniu Ligi Północnej..., s. $89-91$. 
nia się przez spustoszone terytoria w kierunku Moskwy. Nawet Stanisław Poniatowski szacował wiosną 1709 roku straty armii szwedzkiej Karola XII jedynie na 2 tys. ludzi. Do Polski nie przenikały informacje o trudnym położeniu szwedzkich wojsk na Ukrainie, którym coraz bardziej brakowało amunicji, prochu i żywności, a do tego były one nękane chorobami.

Zupełnie inną kwestią jest długotrwałe utrzymywanie się złudzeń dotyczących rzeczywistego przebiegu bitwy połtawskiej. W obozie polsko-szwedzkim po prostu nie przyjmowano do wiadomości napływających zewsząd informacji o całkowitej klęsce armii szwedzkiej. W świetle dotychczasowych doświadczeń i przekonania o pomyślnym dla Szwedów przebiegu całej kampanii wydawało się to niemożliwe. Złudzenia te trwały przez miesiąc. Dopiero przybycie specjalnego gońca z Benderu od Karola XII uświadomiło królowi Stanisławowi, jego najbliższemu otoczeniu i dowództwu szwedzkiemu grozę sytuacji. Jednak nie wszyscy w Polsce zachowywali taką podejrzliwość wobec informacji napływających z Ukrainy. Kanclerz wielki litewski Karol Stanisław Radziwiłł, przebywający wówczas w Janowie Podlaskim, otrzymał 28 lipca 1709 roku wiadomość o klęsce Karola XII i tak ją zanotował w swoim diariuszu: „Król szwedzki d. 13 eiusdem [tego miesiąca] przegrał batalię z carem moskiewskim tak strasznie, że ledwie w kilkaset koni salwował się za Dniepr do państw tureckich"64. Data bitwy połtawskiej co prawda się nie zgadzała, ale sam fakt rosyjskiego zwycięstwa nie podlegał żadnej wątpliwości.

Warto jednak pamiętać, że przesyłanie mało wiarygodnych bądź nawet fałszywych informacji, a także niedawanie wiary niepomyślnym wiadomościom nie dotyczyło wówczas tylko ziem Rzeczypospolitej. Podobnie było choćby i w Szwecji. W latach 1708-1709 do Sztokholmu docierały najrozmaitsze pogłoski mówiące m.in. o zwycięstwie gen. A.L. Lewenhaupta pod Leśną czy o niezwykłym sukcesie Karola XII podczas trzydniowej bitwy, rzekomo stoczonej przez niego w grudniu 1708 roku, podczas której miało zginąć 120 tys. Rosjan, i o zajęciu przez szwedzkiego monarchę Moskwy. Inne wieści natomiast nie ukrywały klęski A.L. Lewenhaupta czy też trudności, na jakie napotykali Szwedzi w Polsce. Bardzo dobrze ten stan rzeczy oddają słowa szwedzkiego historyka Petera Froma: „Niepokój w Szwecji rósł, a wojna propagandowa ze Szwecją nabierała coraz szybszego tempa. Na terenie całej Europy obie strony [szwedzka i rosyjska] kolportowały materiały propagandowe gloryfikujące własne zwycięstwa i przedstawiające przeciwnika w czarnych barwach. Nikt nie wiedział, co jest prawdą, a co nieprawdą" ${ }^{\circ}$.

Niedostatek informacji i mała wiarygodność tych doniesień wynikały jednak również z nieregularnego przesyłania korespondencji między kwaterą Karola XII a Inflantami i sztokholmską administracją oraz między dowódcami wojsk szwedz-

${ }^{64}$ AGAD, AR, dz. VI, t. II - 79, k. 87v, Diariusz czynności Karola Stanisława Radziwiłła 28 VII 1709.

${ }^{65}$ P. From: Klęska pod Połtawą..., s. 216, 268 (cytat). 
kich pozostawionymi w Polsce i Stanisławem Leszczyńskim. Armia szwedzka praktycznie była odcięta zarówno od Inflant, jak i od ziem Rzeczypospolitej przez Rosjan, a także przez działające we wschodnich i południowych województwach Korony i Litwy wojska konfederacji sandomierskiej, wzmocnione po wkroczeniu na Wołyń oddziałów rosyjskich. Niezwykle utrudniało to wzajemne kontakty między Karolem XII a Stanisławem Leszczyńskim ${ }^{66}$. Problem ten wyraźnie jest widoczny w listach Jozafata Michała Karpia. Wynika z nich, że wiadomości z Rosji i Ukrainy były wyrywkowe, czasem przypadkowe i docierały do Polski bardzo rzadko.

\section{Bibliografia}

ANUsik Z.: Karol XII. Wrocław 2006.

BARZDEVIČA M.: Rozpowszechnianie informacji o działaniach wojennych $w$ Rydze $w$ czasie wielkiej wojny pótnocnej. W: Wojny pótnocne w XVI-XVII wieku. Red. B. Dybaś, A. ZiemlewsKa. Toruń 2007, s. $183-187$.

Beskrovnyj L.G.: Strategiâ i taktikarusskoj armii v Poltavskij period Severnojvojny. W: Poltava. K 250-letiû poltavskovo srażeniâ. Red. L.G. Beskrovny et al. Moskva 1959, s. 21-62.

Cieślak E.: Stanisław Leszczyński. Wrocław-Warszawa-Kraków 1994.

Dobrowolski P.: Świat ze słów. Angielskie miesięczniki XVIII w. Media, informacja i opinia publiczna. Warszawa 2018.

Durbas M.: Sekretarz króla Stanisława - agent czy wierny sługa. W: Władza i polityka w czasach nowożytnych. Red. Z. ANUsik. Łódź 2011, s. 17-34.

DygdaŁa J.: Od Torunia do Wilna podróż króla Stanisława zima 1708 roku. „Zapiski Historyczne” 2017, 82, z. 2, s. 85-99.

Gierowski J.A.: Stanisław Bogusław Leszczyński h. Wieniawa (1677-1766), król Polski, książę Lotaryngii. W: IDEm: Na szlakach Rzeczypospolitej w nowożytnej Europie. Red. A.K. Link-LenczowsKi. Kraków 2008, s. 395-414.

Gierowski J.A.: Stanisław Leszczyński w latach 1707-1709 w opiniach dyplomatów francuskich. „Acta Universitatis Wratislaviensis, Historia" 1981, 36, s. 155-164.

Gierowski J.A.: W cieniu Ligi Pótnocnej. Wrocław 1971.

Kroкosz P.: Rosyjskie siły zbrojne za panowania Piotra I. Kraków 2010.

LILJEGREN B.: Karol XII. Gdańsk 2015.

Maliszewski K.: Komunikacja społeczna w kulturze staropolskiej. Toruń 2001.

Materyały do historii Stanisława Leszczyńskiego króla polskiego. Wyd. E. RaCzyńsKi. Poznań 1841.

PerŁakowski A.: Plotki, sprzeczne informacje i gra pozorów. Działalność Stanisława Krosnowskiego, regimentarza Adama Mikołaja Sieniawskiego, hetmana wielkiego koronnego w latach 1707-1709. W: Historia na źródłach oparta. Studia ofiarowane Profesorowi Tadeuszowi Srogoszowi w 65. rocznicę urodzin. Red. A. Stroynowski. Częstochowa 2017, s. 259-278.

PŁowy D.: Poniec 7 XI 1704. Kampania jesienna Karola XII. Tarnowskie Góry 2013.

${ }^{66}$ Ibidem, s. 250; B. Liljegren: Karol XII..., s. 167-168. 
PopioŁek B.: Między prawda a plotką. Prasa rękopiśmienna epoki saskiej jako źródło do historii mentalności. W: Sic erat in fatis. Studia i szkice historyczne dedykowane Profesorowi Bogdanowi Rokowi. T. 2. Red. E. Kościk, R. Żerelik, P. Badyna, F. Wolański. Toruń 2012, s. 295-309.

Porazinski J.: Dezinformacja i propaganda $w$ dobie wielkiej wojny pótnocnej. Jan Stanisław Jabłonowski - moralista i manipulator? W: Między barokiem a oświeceniem. T. 9: Wielkie bitwy. Red. S. ACHremCZyк. Olsztyn 2010, s. 18-24.

Serczyk W.A.: Piotr I Wielki. Wrocław 1990.

SERCZYK W.A.: Poltawa 1709. Warszawa 1982.

WimMER J.: Wojsko polskie w dobie wojny pótnocnej. Warszawa 1956.

Wiśniowiecki J.A.: Ilias Polski (1700-1710). Wyd. P.P. Romaniuk, J. Burdowicz-Nowicki. Warszawa 2018.

Zawisza K.: Pamiętniki Krzysztofa Zawiszy, wojewody mińskiego (1666-1721). Wyd. J. BARToszewicz. Warszawa 1862.

Jerzy Dygdała

The power of delusions - reports on Swedish "victories" in Russia and about the Battle of Poltava reaching Polish royal camp (August 1708-September 1709)

Summary

Often enough in historical literature the following phenomena have been stressed: misinformation of public opinion, disseminating hearsay, and last but not least, stubborn dismissal of reports inconvenient to their recipients and deluding oneself that another news should bring a completely different state-of-affairs. Those characteristic phenomena are clearly visible when one looks into the process of receiving information regarding an unprecedented defeat suffered by the Swedish army of King Charles XII near Poltava in 1709. The supporters of Stanisław Leszczyński, who was allied with the Swedes, along with Swedish officers belonging to his entourage for the lengthy period denied the veracity of the reports and accepted any hearsay regarding Tsar Peter I's alleged defeat at its face value.

Key words: transfer and reliability of onformation, Charles XII, Stanisław Leszczyński, Battle of Potlava 